\title{
Effect of Housing Condition and Environmental Sanitation on the Residents of Oyo State, Nigeria
}

\author{
OWOLABI, Babatunde Oluwaseyi (Ph.D) \\ Department of Urban and Regional Planning, Federal University of Technology Akure, \\ Akure, Nigeria
}

*Corresponding Author: OWOLABI, Babatunde Oluwaseyi, Department of Urban and Regional Planning, Federal University of Technology Akure, Akure, Nigeria

\begin{abstract}
The study investigates effect of housing condition and environmental sanitation in Ogbomoso north local government. The questionnaire designed was randomly administered to 164 residents in the 10 wards of the local government area to obtain relevant information on the socio economic characteristics of the respondents as well as their view on housing and environmental condition. This served as the primary data. Secondary data were collected through the consultation of books, documents, maps and unpublished theses. The result observed that, there is low level of male respondents than the females with 53.0 percent and 45.1 percent respectively. It also revealed that most of the houses were (occupied mostly by tenants 52.4 percent) are face-to-face (70.7 percent), a considerable proportion of the houses are not only deteriorating (62.8 percent) but fairly accessible by roads (25.6 percent). This is coupled with the observed inadequacy of basic facilities and services as reflected in pit latrine constituting (36.6 percent) and bush type (31.7 percent) as the major sanitary system. A significant number of the houses are very dissatisfied in the location of their kitchen. This study recommends that there is a need to educate the public on the importance of environmental sanitation and its impacts on their well being. The government should also provide improved and effective ways of waste collection, potable water and the provision of sewage facilities in order to create a conducive environment, for the health, well-being and sanitary environment of our people and homes.
\end{abstract}

Keywords: Effect, housing condition, environmental sanitation, Resident, Ogbomoso North Local Government, Oyo State, Nigeria

\section{INTRODUCTION}

The problem of inadequate or nonexistent housing has reached crisis proportions globally. The world population passed 6.1 billion in 2001 and is expected to reach 7.9-10.9 billion by 2050, according to the United Nations Population Fund (UNPF). This sheer volume alone exerts enormous pressure to improve existing housing and create new homes. Housing affects health in different ways; a deficient housing can compromise the most basic needs of water, sanitation, and safe food preparation and storage. The consequences of which are rapid spread of communicable and food borne diseases.

There is no doubt that housing is one of the three basic needs of mankind and it is the most important requirement for the physical survival of man after food. It is the maker of human identity, which determines, to a large extent the success of man in life it is also seen as a tool for social development (Agbola 2005). National housing policy (2006) defined housing as the process of providing functional shelter in a neighborhood day-to-day living and activities of individuals and families within the community. It also described housing in all its ramifications as more than shelter since it embraced all social services and utilities that make a community or neighborhood a livable environment. Housing condition is then the totality of the physical, environmental and the satisfaction level of a particular dwelling unit measured against some variable of livability at a particular time.

Brundtland (2006) sees environmental sanitation as a set of actions geared towards improving the quality of the environment and reducing the amount of diseases. By doing so, the hope is that, living conditions will improve and health problems will decrease. The management of water, solid waste, and industrial waste, as well as, pollution and noise control falls under the umbrella of environmental sanitation. Health and well-being concerns of inhabitants in developing societies are associated with the unplanned urban centres and poor sanitary habits among city dwellers. A community with proper sanitation will in turn have improved living conditions, increased health, well-being and economic 
productivity (Elledge, 2003).

\subsection{Statement of Research Problem}

Over the years housing and sanitation issues has been one of the most pressing needs of sustainable human existence on the global surface. After feeding and covering of nakedness, man's utmost priority is to house and protect himself from hostility that pervades the environment and atmosphere within his immediate environment

The sanitary condition in the study area has been worsened as a result of inadequate housing facilities like toilet, drainage, good kitchen, water supply and electricity thereby littering the surroundings with domestic waste, garbage and many others. Thus, the problem of housing and environmental sanitation must be looked into in order to make life more pleasant, convenient, safe, and healthy to man which is the main aim of every urban planning and developing efforts. . As the overall population of man increases, there is need to provide adequate accommodation and quality environment of improved condition. Thus population increases simultaneously with increase in the need for affordable housing and good sanitation facilities (Onibokun 2006). The increase in population in the study area resulted into deterioration of housing quality, unhygienic environment and the beauty of any environment lies on its good housing and sanitary condition. This is so because when environment is clean, the lives of the citizenry are not threatened by illness and diseases.

\subsection{Justification for the Study}

There is a need for man to live in a conducive, functional, health, satisfying environment and housing in a good condition. Housing is one of the basic need necessities of life; everyone wants to have a place of abode which is suitable for human habitation. It is known that housing is essential in human life because without shelter and other fundamental indices of living, like food, security of life and property, man will be adversely affected to the detriment of the development of the sound mind, which is the hub on which the wheel of socio-cultural development is aligned (Agbola, 2005).

The ever increasing population in the modern world has compounded environmental and housing problem (Okedele 2000). Many people live in substandard houses and environments that are unhygienic and sub-human by all standards. Consequent to this, the federal government has continued to work on policies and programmes designed to increase the quality and condition of the environment and housing. However, this work will seek to give a better and clearer view of how housing and environmental condition can be effectively improved.

\subsection{Aim and Objectives}

Aim

The aim of this study is to assess household's perception of housing condition and environmental sanitation of their area with a view to making suggestions towards its improvements.

The objectives are to:

1 Identify the present state of housing and environmental condition in the study area

2 Appraise the perception of residents of the study area about their housing and environmental sanitation.

3 Identify various forms of housing and environmental sanitation problems in each household.

4 Assess the problems of facilities and sanitation management.

5 Explore possible actions that can be taken towards sustainable housing and environmental sanitation in the area.

\subsection{Study Area}

Ogbomoso is in Oyo State and has Five Local Government Areas which are; Ogbomoso North precisely at Kinnira, Ogbomoso South precisely at Arowomole, Ori-ire at Ikoyi, Surulere at Iresa and Ogo-oluwa Local Government area at Ajawa. Ogbomoso is the second largest city in Oyo State after Ibadan. It lies on the plateau of Yoruba land (elevation) 1,200 feet (366m) in an area of savanna and farmland at the intersection of roads from Oyo, Ilorin, Osogbo and Ikoyi founded in the mid $17^{\text {th }}$ century. It remained a minor outpost of the Yoruba Oyo Empire until the beginning of the Muslim 
Fulani conquests of Oyo in the early $19^{\text {th }}$ century. It is one of the nation's largest urban centres that are inhabited mainly by Yorubas, Hausas, Ghanaians and the Fulanis. The settlement of Ogbomoso reflects fairly well, the pattern of movement of people in various parts of what became Nigeria especially.

Ogbomoso region's climate is characterized by uniform moderate, temperate, relative humidity and heavy seasonal rainfall. The annual mean temperature of Ogbomoso region is about $26.20 \mathrm{oc}$ where the highest is in March at 28.7oc and lowest in August at 24.3oc. Ogbomoso South Local Government like other southern regions in Nigeria has four seasons which includes long wet mid March to July, the dry season of August, short wet season of September to October and the long dry season or the harmattan season which lasts from November to mid March

The existing land use in Ogbomoso is characterized by compact development as most areas have developed organically without any form of planning that is they are haphazardly located. Other land uses exist but residential and agricultural land use is the most prominent. Industrial land use is also a feature in the study area as there are small scale industries and provision for industrial reserved areas. Public land uses such as schools, town hall, library, hospital and health facilities, open spaces, cemetery and the likes also exist.

\subsection{Economic Activities}

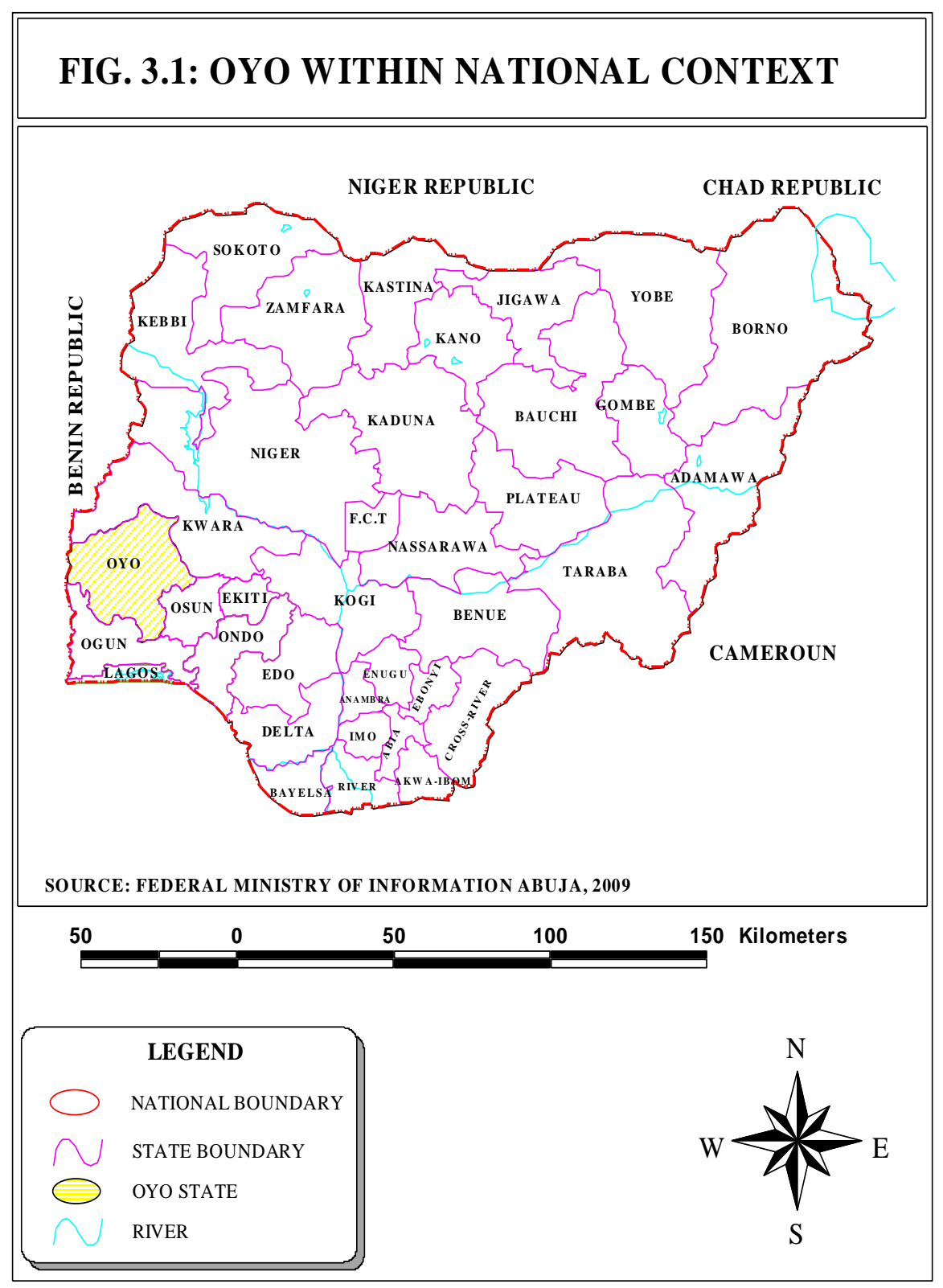

The economic activities of the Ogbomoso people include Hunting, Agriculture and Local Industries. They cultivate stable crops like Yam, Corn, Sorghum and Cassava. These crops are grown for local 
consumption exported. Also, there are special markets with special market days. This is where the people of Ogbomoso bring their goods and products for sale. Examples of such markets are Arada market, Ayeroju, Oja jingo, Oja waso and others. The people of Ogbomoso also weave clothes Aso Oke, Sanya and Kempe a cloth woven from silk brought from Ilorin. Ogbomoso is known for its early wood articrafts and for its unique Koso drum.

Ogbomoso north local government area is located in Ogbomoso, Oyo state, which is located between latitude 7.55 north of the equator and 440 east of the Greenwich meridian. It is located about $105 \mathrm{~km}$ $\mathrm{NE}$ of Ibadan, $53 \mathrm{~km}$ south west of Ilorin and $57 \mathrm{~km}$ north east of Oyo town. The town which was hectares in geographical size in 1950 grew to 1,024 hectares in 1970 and 2,432 hectares in1995 (Popoola, 2000). In a recent study, Ogbomoso was estimated to be 27.49 square kilometers in size in 2003 (Akintola, 2004)

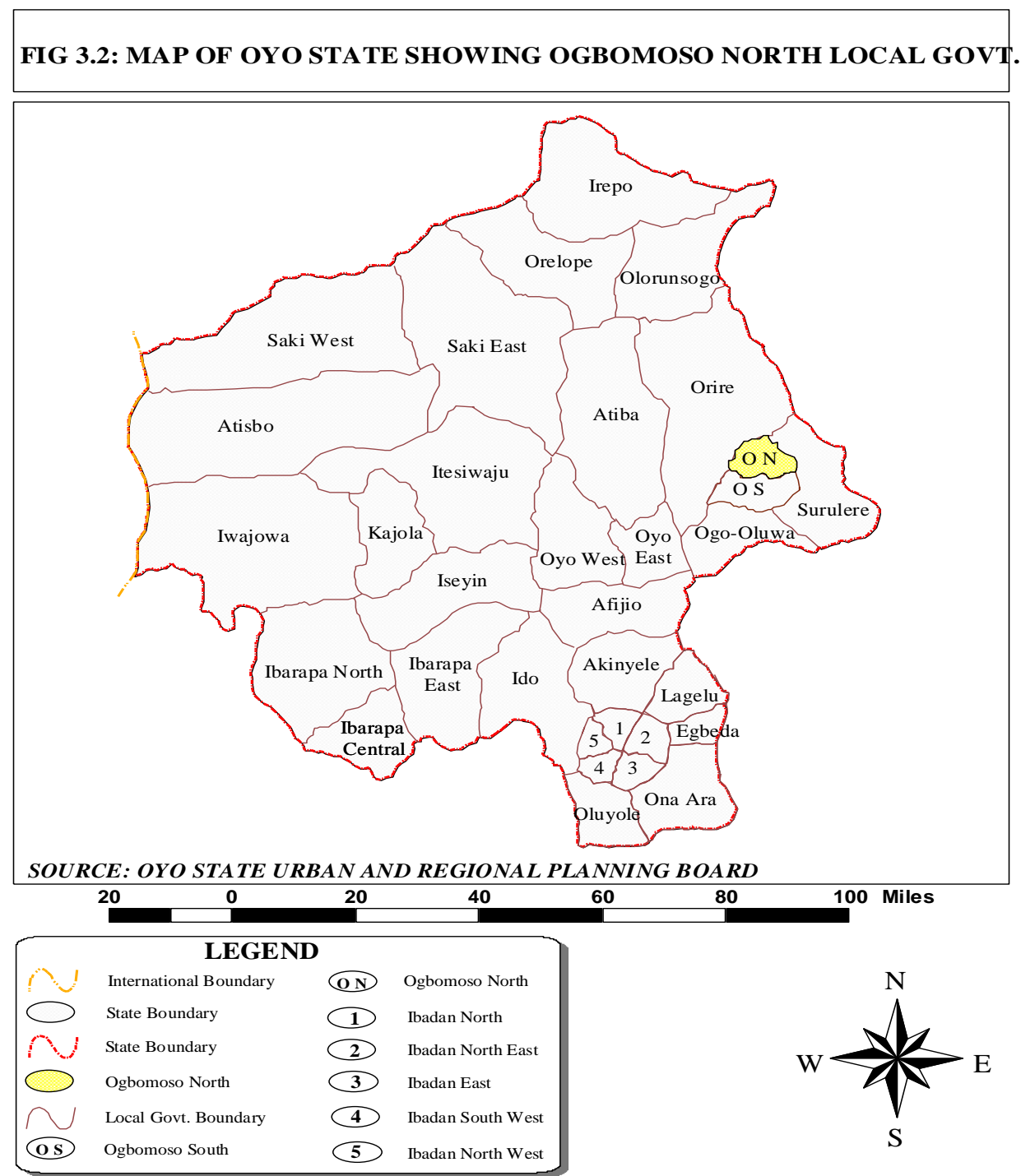

\section{CONCEPTUAL Frame WORK AND LiteratURE REVIEW}

\subsection{Conceptual framework}

Housing, particularly urban housing remains an intractable problem in the less developed countries of the world, Nigeria inclusive. The acute shortage of housing in developing world was the subject of World Bank Report that "the urban poor, typically housed in slums or squatters settlements often have to contend with appalling overcrowding, bad sanitation and contaminated water (Tunde Otubu, 1990). A study of the housing situation reveals that it is characterized by an inadequacy for which a combination of social, economic, demographic and technological factors is responsible. Throughout Africa statistics show quite clearly that urban dwellings are in general, overcrowded and lacking in most elementary amenities and surrounded by a deplorable urban landscape situation (Tunde Otubu, 1990). 
According to Omuojni, E.O (2008) housing is all at once a physical entity, a social artifact, an economic good, a capital stock, status symbol and at times, a political "hot potato". It is defined by National housing policy of 2006 as the process of providing functional shelter in a neighborhood dayto-day living and activities of individuals and families within the community. With this definition, one will ascertain that housing is not just a place of abode alone, but any place which serves as good accommodation and protection against all odds and provide with safety and protection of life and property, privacy, ventilation and good air, natural and artificial lighting spaces and other services such as pipe borne water, good sanitation, electricity, drainage and sewage and many others that makes live worth living. Therefore, any housing unit or neighborhood which lacks the above mentioned facilities and services or maybe they are not effective, this housing unit or neighborhood cannot be regarded as a good housing unit or neighborhood.

The principle on which sanitary environment is based on the residential unit and its immediate surroundings, that is why Onibokun (2006) says that a "pure water and safe removal of waste product is the foundation on which good nutrition and healthy living can be built" i.e a well planned area with the provision of all necessary facilities and services which are in good conditions as the product of sanitary environment. Also, the socio-cultural characteristic level of the inhabitants of a particular area does contribute to level of sanitation. Onibokun (2006) noticed that, "housing as a unit has a profound influence on the health, efficiency, social behavior and welfare of the people.

So, the quality of internal and external surrounding area is termed environmental sanitation, which is the sum total of all conditions provided within and around a housing unit for good standard of living condition, health protection and safety of the occupant or inhabitant of the unit at any point in time. (WHO et al. 2004) on the other hand said that not only does proper sanitation reduce the burden of disease, but it provides secondary benefits such as increasing child school attendance, increasing the economic productivity of communities, as well as assisting in the empowerment of women.

It can then be said that poor household are likely to share toilets, cook in their passages, live in substandard rooms and their domestic animals move freely about the streets and dropping their waste on the streets which generally deteriorate the environment and because of this, they are exposed to more than the high class people who can afford a very good housing and a disease free environment.

\subsection{Literature Review}

\subsubsection{Housing}

The importance of housing to man cannot be overemphasized. Housing is one of the three basic needs of mankind and it is the most important for physical survival of man after provision of food. A deficiency in housing can profoundly affect the health, welfare and productivity of man. It is an indispensable necessity without which man's survival is impossible. Beyond the fabric, services and the contents of the dwelling, housing encompasses that entire surround the dwelling to stimulate healthy living. Housing has to be adequate quantitatively and qualitatively in order to fulfill its basic purposes. The environment also has to be of good quality by providing a sense of well being and satisfaction to its occupants. This is manifested in the physical condition, landscaping, available facilities, and friendliness of neighbors, racial or economic composition or symbolic characteristics (Awotona, 1982).

Housing is defined by National Policy of 2006 as the process of providing functional shelter in a neighborhood day-to-day living and activities of individuals and families within the community. Housing is also described as the totality of all physical environments, largely man-made, in which family live, grow and decline (Agbola, 2005). In the same vein, the national housing policy (2006) described housing in all its ramifications as more than shelter since it embraced all social services and utilities that make a community or neighborhood a liable environment.

Housing and shelter are not the same, this is because in addition to shelter or lodging for human habitation, housing encompasses the immediate environment, sanitation, drainage and all other economic and social activities that make life worthwhile (Otegbulu, 2004). This is because a house which does not have all the facilities, equipment, services and devices for healthful living is not a house but a mere shelter.

The word "housing" conveys different meaning to different people, all depending on their economic, cultural and basic professional background. The emphasis in most studies on housing is on it 
availability or non-availability a theme that runs through most studies is that of shortage which made most housing policies tend to be more heavily towards the construction or production of new units (Omuta, 2004). Again some good research work have been carried out on the nature of environmental problems in some major cities of Nigeria, most of these works have been stewed towards the area and aspect of solid waste management, slum, overcrowding and general state of housing (Okpala et al 2003).

One of such work is the study of Benneh et al (1993) that noted overcrowding as household problem, he believes that homes several rooms, especially if the use of most rooms is restricted to one or two household members that is in such homes there is high probability of overcrowding and congestion which may lead to poor housing condition or sanitation problems.

\subsubsection{Housing Quality in Nigeria}

Housing quality has to do with the physical conditions of the housing units in a particular area in terms of their structural soundness or fitness, ventilation as well as essential facilities such as water, electricity, telephone, services, toilet, bathroom, kitchen etc. housing quality describes the state, nature of standard of housing with respect to minimum or acceptable standards.

Here are some basic conditions that must be satisfied before we can have good, decent, safe, quality housing. They are listed below:

The housing environment particularly, the house must provide adequate privacy, clean air, adequate natural and artificial light and adequate space for playing

$>\quad$ The house must provide adequate opportunity for normal family and community life, easy movement within the house and outdoor living.

$>\quad$ The house must provide adequate protection from accidents, that is, the housing environment particularly the house must be properly constructed to prevent fire accidents, protection against electricity defects and gas poison, injuries at home.

The house must give protection from disease through provision of pure water supply, toilet facilities, food storage facilities and sleeping spaces.

The problems of housing and its quality in Nigeria are enormous and complex. The quality of housing in Nigeria is said to be falling because of the poor or lack of access to facilities. Poverty is also a major determinant in the provision of a house with good condition in the sense that, a low income earner who have large family will have to spend much on feeding that nothing can be solved from the income for housing and if he happens to get the money for housing, his priority will not be to build a quality house but just to have a place of abode not minding the facilities to be included in the house and that is why many still engage in the construction of Brazilian type of houses (face me I face you type of building) up till this day because housing quality means little or nothing to them.

\subsubsection{Concept of Housing Affordability}

Housing affordability is not a feature of housing but a feature of housing services in relation to consumer capacity and desire to own or buy the houses (Stone, 2006). In a study, housing affordability is defined as a link between housing and people (Mengjie et al, 2008). Housing affordability is a selection decision function which is made by a family between housing and nonhousing product expenditure. It reflects a balancing act in the household spending choice that is very subjective. Many studies have agreed that housing affordability measurement is complex.

Apart from income and house price aspects that could show someone's ability to pay house installment, housing affordability could also be seen through education level, types of occupation (Clark, 1994), number of households that work (Feijten, 2010), have children (Quercia, 2003), monthly house installment (Cox, 2010), and housing subsidies (Kutty, 2005). Previous result of studies found that housing affordability index by the majority increasingly low, such as in selected cities across the world.

\subsubsection{Housing Problems in Nigeria}

In particular, housing problem is prevalent in many of Nigerian urban centres. This is an enduring feature of urbanization process. As a result of urbanization, there is now tremendous pressure on housing so much so, that the gap between housing supply and demand in Nigeria continues to widen. 
According to Megbolugbe (2010) the most outstanding of all urban problems, caused by the rapid expansion of urban population, is that of providing housing facilities for the teeming urban population in Nigeria. In an attempt to meet the housing challenges facing the built environment in Nigeria, a number of programmes and recently policies have been articulated and introduced. The first explicitly formulated National policy on housing was launched with fun fare in 1991 with a set goal of providing housing accommodation for all Nigerians by the year 2000. As the set goal failed, the reinvigorated policy by government in 2002 was aimed at providing necessary solution to the hitherto intractable housing crisis in Nigeria (Okewole and Aribigbola, 2006). Internationally, housing problems have received a lot of attention. The United Nations has set aside every first Monday of October as the World Habitat Day. This is to enable people all over the world, especially in the developing countries know the importance of housing.

Challenges of housing in terms of quality and quantity appear to be the same all over the world. The needy have less access to housing while the less needy have greater chances of accessing housing. In Nigeria, housing is generally inadequate in the rural areas in terms of quality, while the major problem in urban areas is more of quantity, although quantity is also an issue. The shortage of housing is one of the factors responsible for the poor environmental quality across Nigeria. In 1991, the national housing policy was promulgated in order to propose possible solutions to the housing problems in Nigeria. Twenty years on, millions of Nigerians are still homeless while many others are living in indecent houses. The paper examines the nature and extent of the housing problem in Nigeria in the context of the National Housing Policy. This paper identifies as the major challenges, poor implementation, corruption, bureaucracy and political instability. It recommends housing finance, cooperatives, use of local building materials, and development of infrastructure, policy implementation and review of the housing policy as possible solutions to the housing problem in Nigeria. In Nigeria, for example, the increasing pace of urbanization and the high tempo of ruralurban migration make housing problem in cities and towns very acute. Available evidence shows that many Nigerians do not have access to good shelter or decent homes (Ibimilua, 2012)

Housing the urban poor is one of the major challenges facing mankind in the twenty-first century. Although studies have shown that the problem of housing is universal, it is however more critical in less developed countries (LDCs), including Nigeria. The challenge of housing the poor is particularly acute in the urban areas of LDCs where an explosive expansion of the urban population due to a high population growth rate and massive rural-urban drift has compounded the housing situation.

In most instances, the urban poor live in over-crowded housing, often in self-made temporary structures in slums and squatter settlements where they exert unprecedented pressure on deteriorating urban infrastructure and social services (Diogu, 2002). Nigeria has one of the highest urban growth rates in the world. The proportion of the Nigerian population living in urban centers has increased phenomenally over the years. While only 7percent of Nigerians lived in urban centers in the 1930s, and 10 percent in 1950, by 1970, 1980 and 1990, 20 percent, 27peercent and 35percent lived in the cities respectively (Okupe, 2002). Over 40 percent of Nigerians now live in urban centre's of varying sizes. The incidence of this population in urban centers has created severe housing problems, resulting in overcrowding in inadequate dwellings, and in a situation in which 60 percent of Nigerians can be said to be "houseless persons" (Federal Government of Nigeria, 2004; Olotuah and Ajenifujah, 2009). Furthermore, almost 75 percent of Nigeria's urban dwellers live in slums (Olotuah, 2005), and in such forms of shelter that are degrading to human dignity (The Built \& Human Environment Review, 2009).These are the urban poor who are subjected to a life characterized by precarious conditions of lack of nutrition and health, little or poor material possessions, substandard housing and a generally degraded environment.

\subsubsection{Environmental Sanitation}

Environmental sanitation is a set of actions geared towards improving the quality of the environment and reducing the amount of disease. By doing so, the hope is that living conditions will improve and health problems will decrease. The management of water, solid waste, and industrial waste, as well as the topic of pollution and noise control, all fall under the umbrella of environmental sanitation (Tunde Opalana 2011). The environmental conditions of a given area may be affected by waste management, the process used to dispose of garbage. How waste is disposed of varies based on living conditions and the accepted standard of living in a geographical area. While some communities provide wastewater treatment and trash collection, others do not, which reduces the ability to control the well- 
being of the environment and its people. When waste is not removed and treated properly, pollution may lead to the spread of disease; when proper disposal and treatment methods are followed, disease

and pollution can usually be reduced.

Environmental sanitation is not limited to the pollution of water and the improper disposal of household waste. When factories or businesses dispose of chemical and physical waste in ways that directly affect the environment, it is often referred to as industrial pollution. For example, while the actual dumping site may occur several miles away from a main source of water, drainage and rainfall can cause chemicals and physical waste to mix with the water supply and pollute it. Some countries have developed a system to properly dispose of industrial waste and help protect the environment; as with household waste, some of these systems incorporate incarceration and landfills into their management strategies (Tunde Opalana 2011).

\subsubsection{Sanitation in Nigeria}

Since the demise of the second republic in 1983, environmental has become a prominent issue in Nigeria countless sanitation edict have been promulgated by state government. Many of these edicts have at least temporarily had considerable impact on the lives of citizen in the major cities. The state preoccupation with sanitation reached a peak in 1985 during the later month of the Buhari regime. Environmental sanitation was chosen as the theme for the fifth phase of the war against indiscipline (W A I). W A I was launched in Kano on $29^{\text {th }}$ July 1985 by the then chief of staff, supreme headquarters, major general Idiagbon. He announced that one million naira will be awarded for the cleanest capital.

\section{RESEARCH METHODOLOGY}

\subsection{Introduction}

Research methodology describes the procedure employed in gathering generating the data needed for carrying out the research work and subsequent technique for processing and analyzing the data will be collected. It will consist of preliminary reconnaissance survey of the study area; sample frame for administering the questionnaire, the questionnaire was design in such a way that the sampling technique would be suitable for the research work/study area.

\subsection{Source of Data}

The data that was obtained from the study area was through primary source (primary data) i.e. collection of data on the field through reconnaissance survey, personal interviews and the use of questionnaire administration to obtain necessary information. The other means are the secondary source for obtaining secondary data, (from other Books, Journals and seminar papers, researches, articles and newspapers).

\subsubsection{Primary Sources}

Data such as socio-economic characteristics of respondents, resident's perception of housing condition and environmental sanitation by respondents was collected from the study area through structured questionnaire administration.

\subsubsection{Secondary Sources}

These was collected from the published and unpublished materials, texts, as well as information from relevant governmental agencies like Ogbomoso local planning Authority, Maps was collected from Ogbomoso north local government. Internet browsing were also made as part of effort to complement work already put on the ground and to have a full knowledge of current issue as regards this research topic in the modern days of the world.

\subsection{Sample Frame}

The population figure for Ogbomoso North Local Government according to the 2006 National Population Census was projected to 2017. This was due to have a reliable population figure to work with; using an annual growth rate of 3.0\% derived from previous 2006 census figures for Oyo state. The 2017 population of the study was projected using this formula:

$\mathrm{P}_{\mathrm{n}}=\mathrm{p} 1(1+\mathrm{r} / 100)^{\mathrm{n}}$ 
$\mathrm{P}_{\mathrm{n}}=$ Base year population (2006)

$\mathrm{I}=$ constant

$\mathrm{n}=$ Difference between the future/ projected and the base year

$\mathrm{r}=$ Growth rate (which is $3.2 \%$ derived from previous 2006 census figures for Oyo state)

\subsection{Sampling Techniques}

The study area comprises of ten(10) geo-political wards namely, abogunde, Aaje, Aguodo/masifa, isale Afon, Okelerin, Isale-Ora, Jagun, Osupa and Sabo/Tara and the number or required housing unit for each ward was randomly selected and in each ward, the first building was sampled at random while the subsequent building were chosen systematically after every fifth building.

\subsection{Instrument of Data Collection}

164 copies of questionnaire were administered. Socio-economic survey was carried out; questions such as gender, age, marital status, occupation, monthly income among others were asked. Questions on housing and environmental sanitation such as type of toilet facility, major source of water supply, mode of solid waste disposal, location of kitchen and many other questions to know the impact of housing and environmental sanitation in the area were contained in the questionnaire.

Table 1.0. Population and Distribution of Questionnaire

\begin{tabular}{|l|l|l|l|l|}
\hline $\begin{array}{l}\text { Index } \\
\text { number }\end{array}$ & Name of political ward & $\begin{array}{l}\text { Population } \\
1991\end{array}$ & $\begin{array}{l}\text { Projected population } \\
\text { to 2017(3.0\%) }\end{array}$ & $\begin{array}{l}\text { Sample size at 0.1\% } \\
\text { of the population. }\end{array}$ \\
\hline 1 & Saja/Isale-ora & 8,914 & 16,582 & 16 \\
\hline 2 & Sabo/Tara, & 6,363 & 11,837 & 12 \\
\hline 3 & Aaje & 9,545 & 17,756 & 18 \\
\hline 4 & Abogunde & 10,181 & 18,939 & 19 \\
\hline 5 & Aguodo/Masifa & 8,274 & 15,392 & 15 \\
\hline 6 & Alaasa & 8,901 & 16,558 & 16 \\
\hline 7 & Isale Afon & 6,373 & 11,855 & 19 \\
\hline 8 & Jagun, & 10,143 & 18,868 & 19 \\
\hline 9 & Okelerin & 8,312 & 15,462 & 15 \\
\hline 10 & Osupa. & 8,254 & 15,354 & 15 \\
\hline Total & & 85,203 & 158,603 & 164 \\
\hline
\end{tabular}

Source: NPC (1991), Author's computation, (2017)

\subsection{Data Analysis and Representation}

The data was analyzed using descriptive statistics such as the frequency distribution and percentages, Graphic representations. To the end, the SPSS software was used.

\section{DISCUSSION OF FINDINGS}

\subsection{Socio Economic Characteristics}

This section presents the findings as well as the analysis of the study. There are four major parts- the socio-economic characteristics of respondents, the assessment of housing conditions in the study area, and the possible relationship between educational background and housing quality.

Table 4.1 Genders of the Respondents

\begin{tabular}{|c|c|c|c|}
\hline \multicolumn{2}{|c|}{ Genders of the Respondents } & Frequency & Percent \\
\hline Valid & Male & 74 & 45.1 \\
\hline & Female & 87 & 53.0 \\
\hline & Total & 161 & 98.2 \\
\hline Mis & & 3 & 1.8 \\
\hline Total & & 164 & 100.0 \\
\hline
\end{tabular}

Source: Author's Field Work, 2017

Table 4.1shows that the proportion of males interviewed are

$(45.1 \%)$ females with $(53.0 \%)$ and $(1.8 \%)$ was missing. This indicates that the females were more involved because most of them are aged people who could not go out but had their business run in front of their houses. 
Effect of Housing Condition and Environmental Sanitation on the Residents of Oyo State, Nigeria

Table 4.2 Age of Respondents

\begin{tabular}{|c|c|c|c|}
\hline \multicolumn{2}{|c|}{ Age of Respondents } & \multirow{2}{*}{$\begin{array}{l}\text { Frequency } \\
34\end{array}$} & Percent \\
\hline Valid & $20-40$ & & 20.7 \\
\hline & $41-60$ & 72 & 43.9 \\
\hline & 60 and above & 55 & 33.5 \\
\hline & Total & 161 & 98.2 \\
\hline Missing & System & 3 & 1.8 \\
\hline Total & & 164 & 100.0 \\
\hline
\end{tabular}

Source: Author's Field Work, 2017

This table 4.2 shows that $20.7 \%$ of the respondents fall within the range of $20-40$ years of age. This is followed by $41-60$ years with $43.9 \%$ while those above 60 years is $33.5 \%$ and the missing falls in the range of $1.8 \%$.

Table 4.3 Marital Status of Respondents

\begin{tabular}{|ll|r|r|}
\hline \multicolumn{1}{|c|}{ MARITAL STATUS } & Frequency & \multicolumn{2}{|c|}{ Percent } \\
\hline Valid & Single & 26 & 15.9 \\
& Married & 125 & 76.2 \\
& Divorced & 10 & 6.1 \\
& Total & 161 & 98.2 \\
Missing & System & 3 & 1.8 \\
Total & & 164 & 100.0 \\
\hline
\end{tabular}

Source: Author's Field Work, 2017

The marital status of respondents as shown in table 4.3 revealed that the higher proportion of the people interviewed were married with $(76.2 \%)$ and $(15.9 \%)$ are single while $(6.1 \%)$ are divorced and $(1.8 \%)$ were missing.

Table 4.4 Educational Status

\begin{tabular}{|c|c|c|c|}
\hline \multicolumn{2}{|c|}{ Educational Status } & Frequency & \multirow[t]{2}{*}{ Percent } \\
\hline Valid & Informal & 58 & \\
\hline & Primary & 48 & 29.3 \\
\hline & Secondary & 45 & 27.4 \\
\hline & Post Secondary & 10 & 6.1 \\
\hline & Total & 161 & 98.2 \\
\hline Missing & System & 3 & 1.8 \\
\hline Total & & 164 & 100.0 \\
\hline
\end{tabular}

Source: Author's Field Work, 2017

Table 4.4 shows that $(35.4 \%)$ of the respondents have informal education, $(29.3 \%)$ of the respondents had primary education, $(27.4 \%)$ of the respondents had secondary education, $(6.1 \%)$ had post secondary education and (1.8\%) was missing.

\subsection{Housing Characteristics}

Table 4.4 Building Types

\begin{tabular}{|c|c|c|c|}
\hline \multicolumn{2}{|c|}{ TYPE OF BUILDING } & Frequency & Percent \\
\hline Valid & Face to Face & 116 & 70.7 \\
\hline & Flat & 16 & 9.8 \\
\hline & Traditional Country & 19 & 11.6 \\
\hline & Duplex & 10 & 6.1 \\
\hline & Total & 161 & 98.2 \\
\hline Missing & System & 3 & 1.8 \\
\hline Total & & 164 & 100.0 \\
\hline
\end{tabular}

Source: Author's Field Work, 2017

Table 4.4 shows that $(70.7 \%)$ of the sampled houses in Ogbomoso north local government are face to face, $(11.6 \%)$ of the respondents live in traditional country, while $(9.8 \%)$ of the respondents live in flat and $(6.1 \%)$ of the respondents live in duplex, while $(1.8 \%)$ was missing. 
Effect of Housing Condition and Environmental Sanitation on the Residents of Oyo State, Nigeria

Table 4.5 Age of Buildings

\begin{tabular}{|c|c|c|c|}
\hline \multicolumn{2}{|c|}{ AGE OF BUILDING } & Frequency & \multirow[t]{2}{*}{ Percent } \\
\hline Valid & Below 10 years & 24 & \\
\hline & $11-20$ years & 44 & 26.8 \\
\hline & 21- 30 years & 41 & 25.0 \\
\hline & Above 40 years & 52 & 31.7 \\
\hline & Total & 161 & 98.2 \\
\hline Missing & System & 3 & 1.8 \\
\hline Total & & 164 & 100.0 \\
\hline
\end{tabular}

Source: Author's Field Work, 2017

The above table 4.5 shows that most of the buildings are relatively old. For instance, as $(31.7 \%)$ of the buildings are above 40 years, followed by $25.0 \%$ for $21-30$ years and $26.8 \%$ for $11-20$ years while $14.6 \%$ falls below 10 years and $1.8 \%$ missing. This indicates that the buildings in the study area have been built for a long time. This reflects on the condition of the building and the need for proper rehabilitation and urban renewal programme.

Table 4.6 Occupancy Type

\begin{tabular}{|ll|r|r|}
\hline OCCUPANCY TYPE & Frequency & \multicolumn{2}{|c|}{ Percent } \\
\hline Valid & Rented & 86 & \multicolumn{2}{c|}{} \\
& Landlord & 12 & 7.3 \\
& Both & 63 & 38.4 \\
& Total & 161 & 98.2 \\
Missing & System & 3 & 1.8 \\
Total & & 164 & 100.0 \\
\hline
\end{tabular}

Source: Author's Field Work, 2017

From the data collected, the proportion of respondents that rented or hired their apartment $(52.4 \%)$ is the highest, which is followed by those building allowing both tenants and landlord is (38.4\%) and those are occupied by the landlord alone are $(7.3 \%)$ and $(1.8 \%)$ was missing.

Table 4.6 State of Building

\begin{tabular}{|ll|r|r|}
\hline State of Building & Frequency & Percentage \\
\hline Valid & Standard & 46 & \\
& Deteriorated & 103 & 28.0 \\
& Dilapidated & 12 & 62.8 \\
& Total & 161 & 7.3 \\
Missing & System & 3 & 98.2 \\
Total & 164 & 1.8 \\
\hline
\end{tabular}

Source: Author's Field Work, 2017

From table 4.6, it is seen that $62.8 \%$ of those buildings are deteriorated, $28.0 \%$ of those buildings are standard houses, while $7.3 \%$ of those houses are dilapidated and $1.8 \%$ missing. The study further shows that all the dilapidated houses needs serious reconstruction or major repairs. It can be linked with the age of building since some of those buildings are over 40 years (See plate 4.1-4.3).

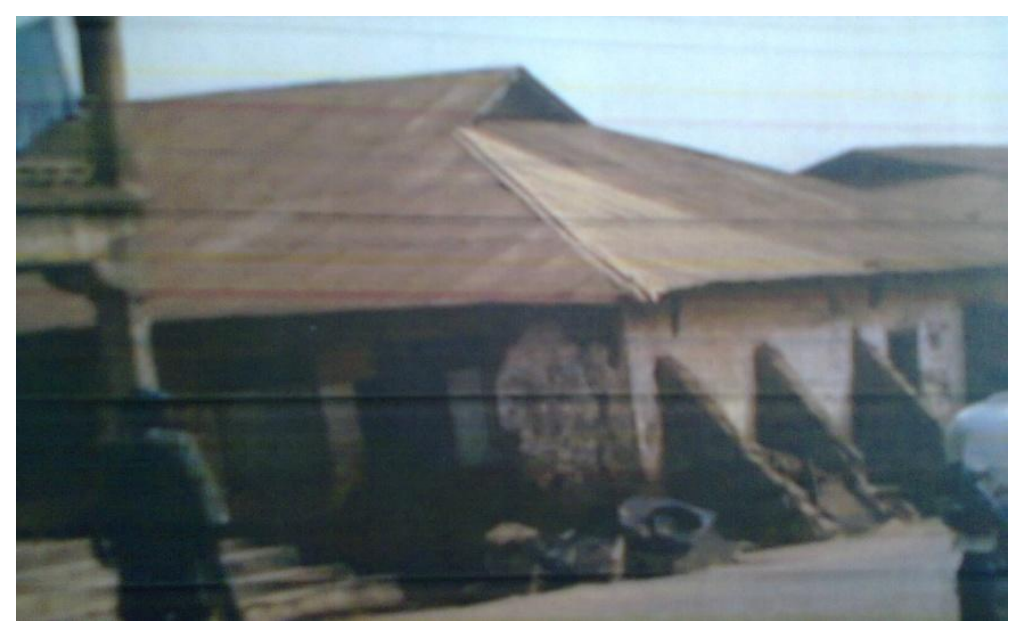

Plate 4.1 Building With support To Prevent It from Collapse, Tara, Ogbomoso

Source: Author's Field Work, 2017

International Journal of Research in Environmental Science (IJRES)

Page | 30 


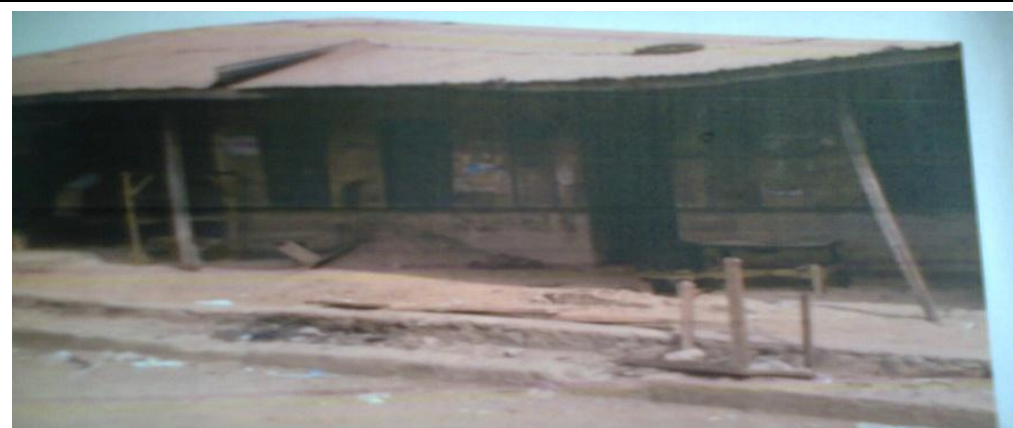

PLATE 4.2 Sustainable dilapidated Building at Osupa, Ogbomoso

Source: Author's Field Work, 2017

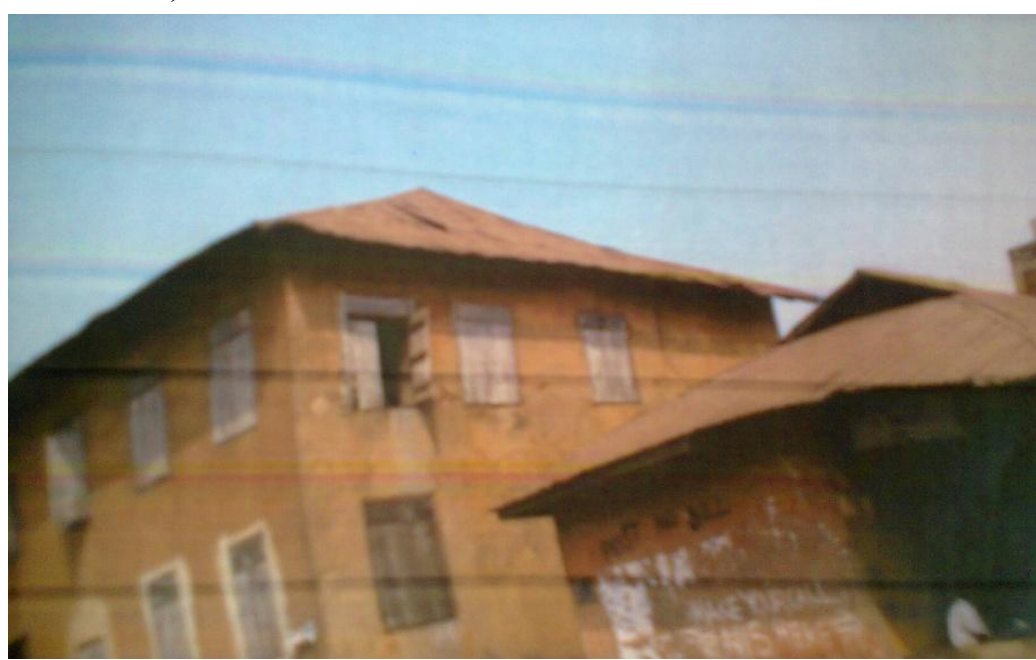

PLATE 4.3 Building with Timber Panel Window and No Anti Burglary Grilles at Jagun, Ogbomoso Source: Author's Field Work, 2017

4.3 Housing Facilities and Condition of Housing

Table 4.7 Type of Toilet Available

\begin{tabular}{|c|c|c|c|}
\hline \multicolumn{2}{|c|}{ AVAILABILITY OF FACILITIES } & Frequency & Percent \\
\hline Valid & Water Closet & 49 & 29.9 \\
\hline & Bush & 52 & 31.7 \\
\hline & Pit Latrine & 60 & 36.6 \\
\hline & Total & 161 & 98.2 \\
\hline Missing & System & 3 & 1.8 \\
\hline Total & & 164 & 100.0 \\
\hline
\end{tabular}

\section{Source: Author's Field Work, 2017}

An examination of building facilities is imperative in a study of this kind. Table 4.7 is a representation of data obtained with regards to the type of toilet in the buildings surveyed. It can be seen that (36.6)\% of those houses had pit latrine, and (31.7\%) had used bushes as toilet, and (29.9\%) had water closet system installed while $(1.8 \%)$ was missing.

Table 4.8 Window Condition

\begin{tabular}{|c|c|c|c|}
\hline \multicolumn{2}{|c|}{ WINDOW CONDITION } & Frequency & Percent \\
\hline Valid & Very Good & 31 & 18.9 \\
\hline & Good & 44 & 26.8 \\
\hline & Fair & 40 & 24.4 \\
\hline & not good & 39 & 23.8 \\
\hline & very bad & 7 & 4.3 \\
\hline & Total & 161 & 98.2 \\
\hline Missing & System & 3 & 1.8 \\
\hline Total & & 164 & 100.0 \\
\hline
\end{tabular}

Source: Author's Field Work, 2017

From table 4.8 , it can be seen that many windows of the buildings in the study area with $(26.8 \%)$ had good windows, $24.4 \%$ had fair windows, $23.8 \%$ of those buildings had not good window, $18.9 \%$ had very good window and $4,3 \%$ had a very bad window and $1.8 \%$ missing. 
Effect of Housing Condition and Environmental Sanitation on the Residents of Oyo State, Nigeria

Table 4.9 Wall Condition

\begin{tabular}{|c|c|c|c|}
\hline \multicolumn{2}{|c|}{ WALL CONDITION } & Frequency & Percent \\
\hline Valid & Very good & 31 & 18.9 \\
\hline & Good & 40 & 24.4 \\
\hline & Fair & 45 & 27.4 \\
\hline & not good & 35 & 21.3 \\
\hline & very bad & 10 & 6.1 \\
\hline & Total & 161 & 98.2 \\
\hline Missing & System & 3 & 1.8 \\
\hline Total & & 164 & 100.0 \\
\hline
\end{tabular}

Source: Author's Field Work, 2017

From table 4.9 above it was discovered that out of the buildings in the study area, $18.9 \%$ had a very good wall condition, $24.4 \%$ had good wall condition, $27.4 \%$ had fair wall condition, $21.3 \%$ had their walls not good, $6.1 \%$ of those buildings walls was very bad while $1.8 \%$ was missing.

Table 4.10 Roof Condition

\begin{tabular}{|c|c|c|c|}
\hline \multicolumn{2}{|c|}{ ROOF CONDITION } & Frequency & Percent \\
\hline Valid & Very good & 33 & 20.1 \\
\hline & Good & 24 & 14.6 \\
\hline & Fair & 57 & 34.8 \\
\hline & not good & 28 & 17.1 \\
\hline & very bad & 19 & 11.6 \\
\hline & Total & 161 & 98.2 \\
\hline Missing & System & 3 & 1.8 \\
\hline Total & & 164 & 100.0 \\
\hline
\end{tabular}

Source: Author's Field Work, 2017

From table 4.10 , it is seen that only $20.1 \%$ of the building unit in the study area had a very good roof condition, $14.6 \%$ had good roof condition, $34.8 \%$ had fair condition, $17.1 \%$ was not good, $11.6 \%$ had a very bad roof condition and $1.8 \%$ was recorded missing

Table 4.11 Floor Condition

\begin{tabular}{|c|c|c|c|}
\hline \multicolumn{2}{|c|}{ FLOOR CONDITION } & Frequency & Percent \\
\hline Valid & Very good & 31 & 18.9 \\
\hline & Good & 32 & 19.5 \\
\hline & Fair & 52 & 31.7 \\
\hline & not good & 33 & 20.1 \\
\hline & very bad & 13 & 7.9 \\
\hline & Total & 161 & 98.2 \\
\hline Missing & System & 3 & 1.8 \\
\hline Total & & 164 & 100.0 \\
\hline
\end{tabular}

Source: Author's Field Work, 2017

From table 4.11 , it is seen that only $18.9 \%$ of the building units in the study area had a very good floor condition, $19.9 \%$ had good floor condition, $31.7 \%$ floor of the buildings was fair, $20.1 \%$ was not good and $7.9 \%$ had a very bad floor condition while $1.8 \%$ was missing

Table 4.12 Ceiling Condition

\begin{tabular}{|c|c|c|c|}
\hline \multicolumn{2}{|c|}{ CEILING CONDITION } & Frequency & Percent \\
\hline Valid & Very good & 37 & 22.6 \\
\hline & Good & 25 & 15.2 \\
\hline & Fair & 36 & 22.0 \\
\hline & not good & 23 & 14.0 \\
\hline & very bad & 40 & 24.4 \\
\hline & Total & 161 & 98.2 \\
\hline Missing & System & 3 & 1.8 \\
\hline Total & & 164 & 100.0 \\
\hline
\end{tabular}

Source: Author's Field Work, 2017

The survey in table 4.12 shows that $22.6 \%$ of those buildings had very good ceiling condition, $15.2 \%$ of the buildings had good ceiling, $22.0 \%$ of the houses in the study area had fair ceiling condition, $14.0 \%$ ceilings was not good, $24.4 \%$ of the building had very bad ceiling and $1.8 \%$ missing. 
Effect of Housing Condition and Environmental Sanitation on the Residents of Oyo State, Nigeria

Table 4.13 Satisfactory Level of Toilet Location

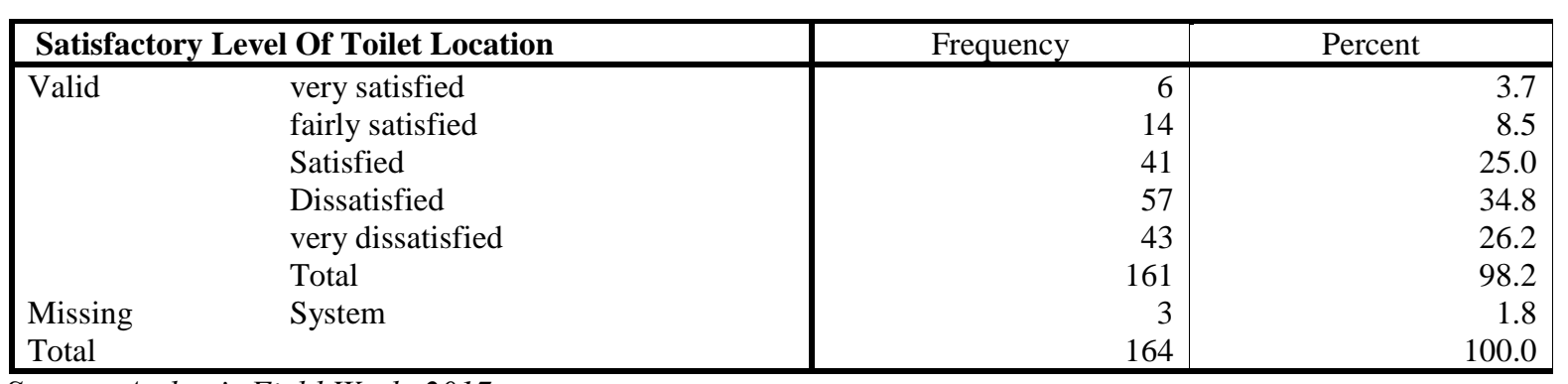

Source: Author's Field Work, 2017

The table 4.13 above shows that $3.7 \%$ of the cases surveyed had their toilet location very satisfied, $8.5 \%$ of the respondents had their toilet location fairly satisfied and $25.0 \%$ of the surveyed area are satisfied in the location of their toilet, while 34.85 are dissatisfied, 26.25 are very dissatisfied in their toilet location and $1.8 \%$ was missing.

Table 4.14 Drainage Condition

\begin{tabular}{|c|c|c|c|}
\hline \multicolumn{2}{|c|}{ DRAINAGE CONDITION } & Frequency & Percent \\
\hline Valid & very satisfied & 9 & 5.5 \\
\hline & fairly satisfied & 20 & 12.2 \\
\hline & Satisfied & 27 & 16.5 \\
\hline & Dissatisfied & 36 & 22.0 \\
\hline & very dissatisfied & 69 & 42.1 \\
\hline & Total & 161 & 98.2 \\
\hline Missing & System & 3 & 1.8 \\
\hline Total & & 164 & 100.0 \\
\hline
\end{tabular}

Source: Author's Field Work, 2017

The result of the analysis showed that $5.5 \%$ of the drainage in the study area are very satisfied, $12.2 \%$ of the drainage are fairly satisfied, $16.5 \%$ of the drainage are satisfied, $22.0 \%$ of the drainage are dissatisfied, $42.1 \%$ of the drainage in the study are very dissatisfied, and $1.8 \%$ missing (see table 4.14).

\subsection{Environmental Sanitation}

Table 4.15 Refuse Collections

\begin{tabular}{|c|c|c|c|}
\hline \multicolumn{2}{|c|}{ REFUSE COLLECTION } & Frequency & Percent \\
\hline Valid & very satisfied & 8 & 4.9 \\
\hline & fairly satisfied & 9 & 5.5 \\
\hline & Satisfied & 61 & 37.2 \\
\hline & Dissatisfied & 54 & 32.9 \\
\hline & very dissatisfied & 29 & 17.7 \\
\hline & Total & 161 & 98.2 \\
\hline Missing & System & 3 & 1.8 \\
\hline Total & & 164 & 100.0 \\
\hline
\end{tabular}

Source: Author's Field Work, 2017

The result of the analysis showed that $4.9 \%$ of those houses are very satisfied in their refuse collection, $5.5 \%$ are fairly satisfied, $37.2 \%$ are satisfied, $32.9 \%$ are dissatisfied and $17.7 \%$ are very dissatisfied and $1.8 \%$ was missing (see table 4.15 ).

Table 4.16 Sanitation Conduct

\begin{tabular}{|c|c|c|c|}
\hline \multicolumn{2}{|c|}{ SANITATION CONDUCT } & Frequency & Percent \\
\hline Valid & very satisfied & 6 & 3.7 \\
\hline & fairly satisfied & 16 & 9.8 \\
\hline & Satisfied & 74 & 14.1 \\
\hline & Dissatisfied & 41 & 25.0 \\
\hline & very dissatisfied & 41 & 45.6 \\
\hline & Total & 161 & 98.2 \\
\hline Missing & System & 3 & 1.8 \\
\hline Total & & 164 & 100.0 \\
\hline
\end{tabular}

Source: Author's Field Work, 2017 
The study revealed that $3.7 \%$ of the residents are very satisfied in their sanitation conduct, $9.8 \%$ of the residents are fairly satisfied in their sanitation conduct, $14.1 \%$ are satisfied based on their sanitation conducts and $25.0 \%$ are dissatisfied in their sanitation conduct while $45.6 \%$ of the residents are very dissatisfied in their sanitation conduct and $1.8 \%$ was recorded missing (see table 4.16)

Table 4.17 Disposal Methods

\begin{tabular}{|c|c|c|c|}
\hline \multicolumn{2}{|c|}{ DISPOSAL METHODS } & Frequency & Percent \\
\hline Valid & very satisfied & 1 & 3.7 \\
\hline & fairly satisfied & 17 & 10.4 \\
\hline & Satisfied & 62 & 37.8 \\
\hline & Dissatisfied & 46 & 28.0 \\
\hline & very dissatisfied & 30 & 18.3 \\
\hline & Total & 161 & 98.2 \\
\hline Missing & System & 3 & 1.8 \\
\hline Total & & 164 & 100.0 \\
\hline
\end{tabular}

Source: Author's Field Work, 2017

The table 4.17 above shows that $3.7 \%$ of the respondents are very satisfied in their method of disposal, $10.4 \%$ of the respondents are fairly satisfied in their method of disposal and $37.8 \%$ of the respondents are satisfied in their method of disposal, while $28.0 \%$ are dissatisfied, $18.3 \%$ are very dissatisfied in their disposal method and $1.8 \%$ was missing.

Table 4.18 Quality of the Environment

\begin{tabular}{|c|c|c|c|}
\hline \multicolumn{2}{|c|}{ QUALITY OF THE ENVIRONMENT } & \multirow[t]{2}{*}{ Frequency } & Percent \\
\hline Valid & very satisfied & & 7.9 \\
\hline & fairly satisfied & 30 & 18.3 \\
\hline & Satisfied & 30 & 18.3 \\
\hline & Dissatisfied & 48 & 29.3 \\
\hline & very dissatisfied & 40 & 24.4 \\
\hline & Total & 161 & 98.2 \\
\hline Missing & System & 3 & 1.8 \\
\hline Total & & 164 & 100.0 \\
\hline
\end{tabular}

Source: Author's Field Work, 2017

From the table 4.18 above, it was revealed that $7.9 \%$ of the environment are very satisfied in the quality of their environment, $18.3 \%$ are fairly satisfied, $18.3 \%$ are satisfied, $29.3 \%$ are dissatisfied, $29.3 \%$ are very dissatisfied in the quality of their environment and $1.8 \%$ was missing.

Table 4.19 Satisfactory Level of Residents' Behavior

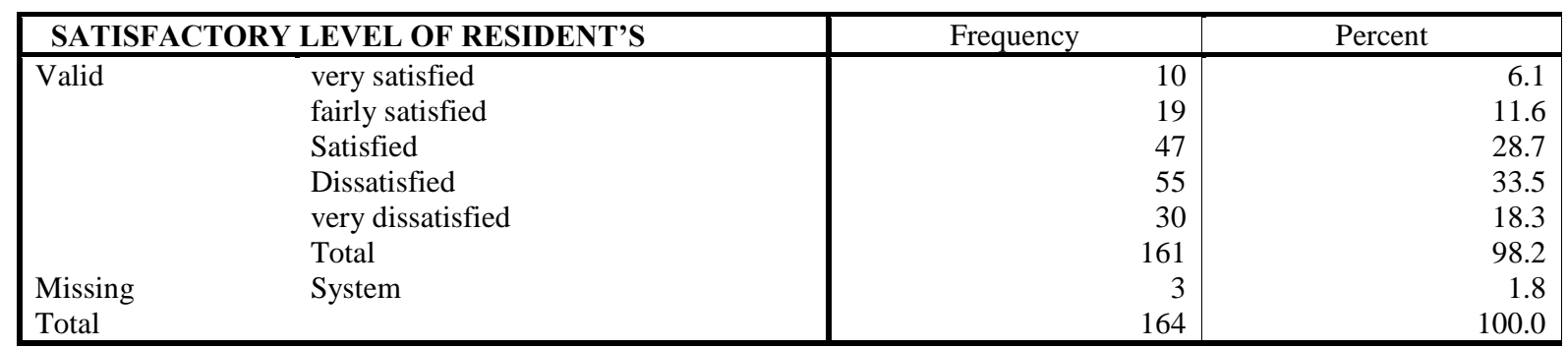

Source: Author's Field Work, 2017

The behavior of people in an environment is very important because it will determine the cleanliness of the surrounding. From the survey carried out, it was revealed that $6.1 \%$ of the residents have very satisfied behavior, $11.6 \%$ of the residents have fairly satisfied behavior, $28.7 \%$ have satisfied behavior, $33.5 \%$ are dissatisfying in their behavior and $18.3 \%$ have very dissatisfying behavior as regards their environment and $1.8 \%$ missing (see table 4.19 ).

Table 4.20 Do You Think the Maintenance of Your House and Entire Surrounding is Necessary

\begin{tabular}{|c|c|c|c|}
\hline $\begin{array}{l}\text { Do you } \\
\text { and enti }\end{array}$ & $\begin{array}{l}\text { tenance of your house } \\
\text { is necessary }\end{array}$ & Frequency & Percent \\
\hline \multirow[t]{3}{*}{ Valid } & Yes & 160 & 97.6 \\
\hline & No & 1 & .6 \\
\hline & Total & 161 & 98.2 \\
\hline Missing & System & 3 & 1.8 \\
\hline Total & & 164 & 100.0 \\
\hline
\end{tabular}

Source: Author's Field Work, 2017 
From the data obtained in the study area, $97.6 \%$ of the respondents regarded maintaining their house and the entire surroundings as important and necessary while $.6 \%$ regarded it as not necessary and $1.8 \%$ was not missing (see table 4.20 )

\section{RECOMMENDATION AND CONCLUSION}

This section summarizes the findings of the study. It states in conclusive terms, the general and the specific observations on the educational level of respondents in the area, their housing conditions and environmental sanitation based on the examination of certain indices. The next section presents the suggestions that are considered relevant to solving the various housing problems based on the data analysed in this study, hence the conclusion of the study.

\subsection{Recommendations}

This study has been able to establish the fact that housing conditions are deplorable in the study area. This section, however seeks to suggest possible solutions to the problems. They are as follows:-

Having realized that there is a relationship between education and housing conditions, there is a need to educate the public. While it may not be realistic to suggest higher education for all, education regarding the importance of providing necessary facilities, and putting such facilities to good use should be encouraged. Furthermore, infrastructure should be provided by the government so that the masses can enjoy their living conditions. Infrastructure such as public water supply, electricity and waste disposal facilities will encourage good housing and environmental condition.

Also, town planning authority should be more efficient in its development control measures. They should ensure that plans conform with the planning principles before approval is made.

Urban development and restoration should be a major concern of government in order to reduce the environmental stress experienced in the urban centres. This is achievable with major investments committed to urban infrastructure and services. This however requires the will of government in tackling frontally the urban poverty plaguing the nation.

Upgrading the environment of in- house and neighborhoods facilities and services is highly needed in the area. Government should try and give attention in terms of policies and programmes such as enlightenment campaigns on how to effectively take care of one's surrounding. They should also try to enforce any authority which is in control of waste management to arrest and if possible to sue anybody found dumping all the necessary facilities needed foe waste disposal and storage for easier evacuation of them.

There is a proverb which says, "Charity begins at home", so people should try and make sanitation part of their day to day ways of living, they should see their environment as a living organism which, when altered or deformed will have a very big effect on them.

\subsection{Conclusion}

This study has focused on impact of housing condition and environmental sanitation in Ogbomoso north local government. The condition of housing and environmental sanitation in the study in the study area is deteriorating due to inadequate infrastructure such as, drainage, refuse disposal system to mention a few, lack of proper maintenance of buildings, the age of the buildings and the socioeconomic status of the respondents such as their level of education, occupational status and income level. The study has again brought to the fore, crucial matters regarding housing and the deplorable conditions in which the vast majority of Nigerians live. The truth of the matter is saddening, and is not an issue to be taken with levity hands. It is unfortunate however, that this situation has persisted for too long without any hope of alleviation in sight. It is hoped that in the next too distant future, when a similar study is carried out, the result will depicts a different situation.

Finally, in order to create a conducive environment, for the health, well-being and sanitary environment of our people and homes, there should be improved and effective ways of collecting waste, provision of potable water supply, provision of sewage facilities and finding solution to overcrowing and poor living condition.

\section{REFERENCES}

Agbola, T.: Assessing Private Sector Participation in Housing Delivery in Nigeria" A paper presented at a One Day Continuing Professional Development Workshop of the Ogun state Chapter of the 
Nigerian Institution of Estate Surveyors and Valuers, in Gateway Hotel, Abeokuta. October 28, 2003 (2003).

Ajenifulah A.O (2009) Architectural Education and Housing provision in Nigeria" In CEBE Transaction, Journal of centre for education in the built environment Cardiff University, UK, 6(1), 86- 102.

Awotona, Aderele. "A contextual analysis of architectural, planning and housing development in rural Nigeria, journal of the Nigerian institute of architects, vol.4, NO. 1. January

Bascom, 1995: "urbanization among the Yorubas", American journal of sociology LX (5) pp 446454.

Built and human environment Review, (2009). Journal for Environmental science.

Elledge, M. F. 2003, Sanitation Policies: Thematic Overview Paper, IRC International Water and Sanitation Centre.

Federal government of Nigeria, FGN (2004) national housing policy for Nigeria, ministry of works and housing, Abuja.

Feiten, p. (2010) Boook review of Janine Meesters: The meaning of activites in the dwelling and residential environment: A structured approach in people- environment relations. Roolijn, 43 (1), 71-73.

Gotaas, H.B. (1954). Public health aspects of waste disposal by composting. Am J Public Health Nations Health. Mar; 44(3):339-348.

Kpatrick Kir (1980), "chamber universal leaner dictionary Edinburgh" chamber Ltd.

Mabogunje, A.L. 1978. Shelter provision in developing countries: The influence of standards and criteria. Chichester: John Wiley and Sons.

Megbolugbe, I.F., 1983. The Hopes and Failures of Public Housing in Nigeria. Third World Planning Review., 5(4): 349-367.

Mengjie, L, reed, R.G and WU, H.(2008), “ challenges facing housing affordability in Beijing in

the $21^{\text {st }}$ century' in the international journal of housing markets and analysis, Vol.1, no.3, pp. 275-287

Okewole, I.A and Aribigbola, A(2006).: Innovations and sustainability in Housing Policy Conception and Implementation in Nigeria. Pp. 414-420. In: The Built Environment: Innovation Policy and Sustainable Development. I.A. Okewole, A., Ajayi, A. Daramola, K. Odusanmi and O. Ogunba (Eds.). Covenant University, Ota, Ogun State, Nigeria.

Okpala et al 2003, "institutional problems in the management of Nigeria urban environmental, NISER monograph series, Ibadan No 15.

Olutuah, A,O (2009): the physical and socio-economic dimension to housing quality: an empirical investigation of a city suburb" African Journal of science, vol.4 no 1 august, pp. 799-810.

Olutuah, A.O., (2005). Housing Poverty, Slum Formation and Deviant Behavior. Department of Architecture, Federal University of Technology, Akure.

Onibokun Poju (2006). "Issues in Nigerian housing". A bibliography review NISER Ibadan:

Otegbulu, methodology for improved natural resources (Environment).

Tunde Opalana (2011). Property and Environment, Nigerian tribute 10-29.

Citation: Owolabi. B. O., " Effect of Housing Condition and Environmental Sanitation on the Residents of Oyo State, Nigeria ", International Journal of Research in Environmental Science, vol. 3, no. 3, p. 17, 2017. http://dx.doi.org/10.20431/2454-9444.0303003

Copyright: () 2017 Authors. This is an open-access article distributed under the terms of the Creative Commons Attribution License, which permits unrestricted use, distribution, and reproduction in any medium, provided the original author and source are credited. 